\title{
Design of Electrical Setting Protection System Indarung VI Cement Plant (Case Study New Cement Plant Construction at PT Semen Padang)
}

\author{
Dian Eka Prasetyawan \\ Department of Maintenance, PT Semen Padang-Indonesia \\ dian.prasetyawan@sig.id
}

\begin{abstract}
Along with the rapid development of technology and the development of civilization, electrical energy is very important in all fields. This research will conduct a study on the electrical protection system design of PT Semen Padang's Indarung VI Cement Plant using the ETAP 12.6 software. PT Semen Padang's Indarung VI Cement Plant uses three transformers of $150 / 6.3 \mathrm{kV}$ of 30/35 MVA (ONAN / ONAF) and each Main Substation has substations that will supply all the loads to be used. The power flow study shows that the addition of a capacitor bank and a tap changer setting will improve the power factor and voltage of the system, thereby reducing the power supply sent by PLN. The short circuit study shows that the largest short circuit current, which is $35 \mathrm{kA}$, can be protected by a circuit breaker with a breaking capacity of $40 \mathrm{kA}$. The protection system coordination study shows that the results of the overcurrent relay setting can protect the electrical system of Indarung VI Cement Plant selectively and safely.
\end{abstract}

CCS CONCEPTS • Industry Applications • Product Design and Development

Additional Keywords and Phrases: Breaking Capacity, Power Factor, ETAP 12.6, Over Current Relay, Tap Changer, Capasitor Bank, Cement Plant.

ACM Reference Format:

NOTE: This block will be automatically generated when manuscripts are processed after acceptance

\section{INTRODUCTION}

In 2016, the construction of a new cement plant, Indarung VI, was carried out. so that we need an electrical protection system design at Indarung VI cement plant. The electrical system at Indarung VI cement plant PT. Semen Padang has interconnections with the Teluk Sirih (Bungus) Substation, Pauh Limo Substation, Ombilin Substation with voltage sharing, namely the $150 \mathrm{kV}$ system, the $6.3 \mathrm{kV}$ system, the 0.7 $\mathrm{kV}$ system, the $380 \mathrm{~V}$ system and the $110 \mathrm{VDC}$ system. The planning, design and operation of power systems require a continuous and thorough analysis to evaluate the performance of current systems and to establish the effectiveness of alternative plans for system development. Planning, design, and operation of industrial and commercial power systems requires some research to assist in the evaluation of initial performance and future system conditions. The studies needed for this problem are power flow studies, cable characteristics studies, short circuit studies, protection equipment coordination studies, stability studies, and motor starting studies..

Based on the description above, the problem statements are compiled in this paper such as:

a. How big is the capacity of the equipment in the electrical system of PT Semen Padang's Indarung VI cement plant?

b. What is the value of the short circuit current and the capability of the equipment in the electrical system of PT Semen Padang's Indarung VI cement plant when there is a short circuit fault?

c. How is the calculation of protection relay settings and protection relay coordination in the electrical system of PT Semen Padang's Indarung VI cement plant?

Design of this system aims such as :

a. Calculate the capacitor bank and tap changer to get the voltage and power factor values according to the standard.

b. Calculate the amount of short circuit current on each bus to get the breaking capacity value and the protection setting data input.

c. Calculating equipment electrical setting protections and current characteristic curves working time of relays for protection system coordination.

Benefit of this design to get an efficient, safe, and economical electrical protection system design so that it can be used as a consideration for PT Semen Padang in designing the electrical system of PT Semen Padang's Indarung VI cement plant.

\section{LITERATURE REVIEW}

The electric power system consists of three main components, namely the electric power building system, the electric power transmission system and the electric power distribution system. Generators, transformers, 
transmission lines and loads are the basic components that make up an electric power system. For the purposes of designing and analyzing the power system, a diagram is needed that can represent each component of the electric power system. Commonly used diagrams are single line diagrams and impedance diagrams or reactance diagrams. Below is a simple one-line electric power system diagram.

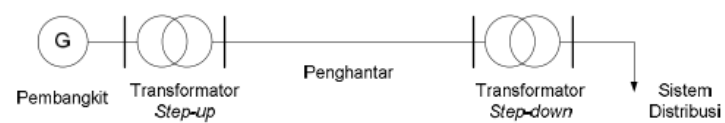

Figure 2.1 One Line Diagram of the Electric Power System.

General Power Flow Equations

Real and reactive power on a bus I have the following equation:

$$
P i-j Q i=V i * I i
$$

By obtaining the voltages on each bus, the amount of power flow between the connected buses can be calculated. The amount of current flowing from bus $i$ to bus $\mathrm{j}$ is:

$$
I_{i j}=\left(V_{i}-V_{j}\right) Y_{i j}+V_{i} \frac{Y_{i j}^{\prime}}{2}
$$

Where :

$Y_{i j} \quad:$ wire admittance $\mathrm{i}-\mathrm{j}$

$Y_{i j}^{\prime} \quad:$ admittance shut wire $\mathrm{i}-\mathrm{j}$

$V_{i} \frac{Y_{i j}^{\prime}}{2}$ : contribution of current to bus I by shunt current

By knowing the current flowing from bus $\mathrm{i}$ to bus $\mathrm{j}$, it can be calculated the amount of power flow flowing from bus i to bus $\mathrm{j}$.

$$
\begin{aligned}
& P i-j Q i=V i * I i=V i *\left[\left(V_{i}-V_{j}\right) Y_{i j}+V_{i} \frac{Y_{i j}^{\prime}}{2}\right] \\
& P i j-j Q i j=V i *\left(V_{i}-V_{j}\right) y_{i j}+V i * V_{i} \frac{Y_{i j}^{\prime}}{2}
\end{aligned}
$$

Meanwhile, the power flow that flows from bus $\mathrm{j}$ to bus $i$ is:

$$
P j i-j Q j i=V j *\left(V_{j}-V_{i}\right) y_{i j}+V j * V_{j} \frac{Y_{i j}^{\prime}}{2}
$$

By adding algebraically between equation (2.3) and equation (2.5), the losses in the $\mathrm{i}$ to $\mathrm{j}$ transmission wire line are obtained.

\section{Power Flow Solution Method}

The study of the flow of power in a power system is a very important study to be able to calculate the voltage and current in different parts of the electric power system. This is important not only for designing components of the electric power system such as generators, salutants, transformers, element shuts, and others. So that these components can also withstand pressure during steady state operation. Furthermore, for a fairly economical operation, the system losses must be put at a low value taking into account the various constraints and risks when the system enters an unstable mode, the operation must be kept in check The power flow study shows the performance and power flow (real and reactive) for a certain state when the system works during a steady state.

\section{Short Circuit Interference Analysis}

Short Circui Disturbance is an abnormal condition in a power system. Disturbances are divided into 2, namely:

1. Internal Disorders

The disturbance that occurs in the transformer protection area, both inside the transformer and outside the transformer is limited to the location of the CT placement.

2. External Disturbances

Interference that occurs outside the transformer protection area. Generally, this disturbance occurs in the network that will be felt and has an impact on the resistance of the primary and secondary / tertiary transformers.

Standard used for short circuit analysis

Industry standards have defined specific analytical techniques that adhere to appropriate guidelines to answer questions about $\mathrm{AC}$ and DC derating in multimachine systems [7]. This is also closely related to adjusting the existing switchgear rating structure. Specific standards are ANSI for North America and IEEE C37 and IEC 60909.

\section{Protection Equipment Coordination}

The protection system is a very important part in an electric power installation, apart from protecting the main equipment in the event of a short circuit fault, the protection system must also be able to secure undisturbed areas and separate disturbed areas. Thus, the disturbance does not spread and the losses arising from the disturbance can be minimized. The substation protection relay as shown in Figure 2.1 consists of:
a. Power transformer protection relay
b. Busbar protection relay (coupling)
c. Feeder protection relay

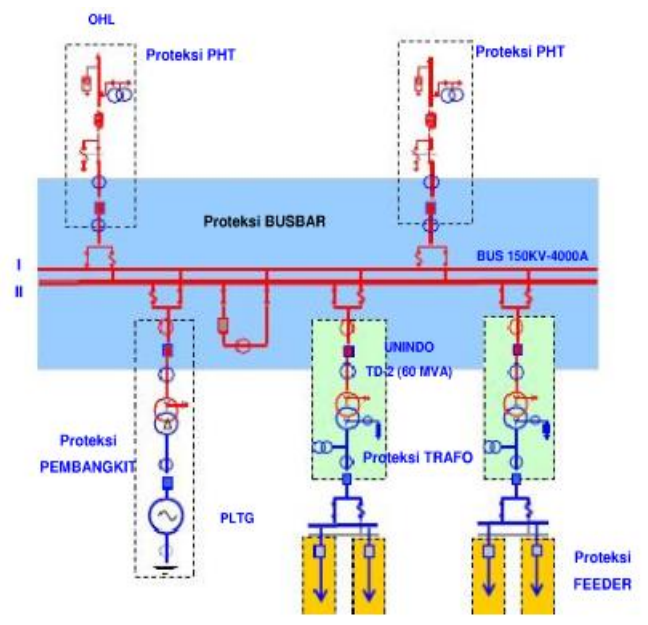

Figure 2. 1 The substation protection diagram 


\section{METHODOLOGY}

The design methodology in designing the Electrical Setting Protection System Indarung VI Cement Plant are : A. Data collection

Data collection is in the form of data from the entire electrical system which will be analyzed as follows:

1. Power Grid Data

2. Data Bus

3. Transformer Data

4. Motor Load and Lump Data

5. Channel Data

6. Data Protection Equipment.

\section{B. Data Processing}

Data processing will be related to power flow analysis, short circuit analysis, coordination of protection equipment, and calculation of tap changers, capacitor banks, and current relay settings.

C. Modeling and Simulation of Electrical Systems in ETAP Software 12.6, consist of :

1. Design a single-line diagram of the Indarung VI Cement Plant of PT. Semen Padang uses ETAP12.6 software.

2. Enter all the parameters of the electrical components to be used.

3. Power flow simulation.

4. Simulation of short circuit fault.

5. Simulation of protection equipment coordination.

D. Calculation and analysis, consist of :

1. Tap changer and capacitor bank settings.

2. Check the value of voltage, current, power and power factor.

3. Check the circuit breaker rating.

4. Checking the results of the protection and coordination settings is safe or not, when not then resetting is done again.

\section{RESULT AND DISCUSSION}

\subsection{System Modeling}

ETAP is used to simulate load flow, short circuit and coordination of protective equipment. Each piece of equipment must be modeled per input data with a view to obtaining accurate results. The first step in modeling is to prepare a Single Line Diagram (SLD). SLD is a simple diagram of electricity and provides a simple understanding of the entire network. Single Line Diagram of Indarung VI Substation is shown in ANNEX 1 .

\subsection{Input Data}

4.2.1 Power Grid

The power plant from PLN to Indarung substation is modeled by an external network. Power is sent from PLN via two UGC circuits. Each UGC circuit can only provide one busbar. The external network is set as swing mode. In the calculation of the power flow, the mode (linked to a synchronous generator or external network) performs a balance in the system.

Table 4.1 Data Power Grid.

\begin{tabular}{ccccccccccc}
\hline \multicolumn{2}{c}{ Ikss (Amp) } & \multicolumn{3}{c}{ Positive Seq. } & \multicolumn{3}{c}{ Negative Seq. } & \multicolumn{3}{c}{ Zero Seq. } \\
lph & ${ }_{\text {3ph }}$ & R1 & X1 & Z1 & R2 & X2 & Z2 & Ro & Xo & Z \\
\hline 10407 & 8696 & 0.005 & 0.049 & 0.049 & 0.008 & 0.049 & 0.049 & 0.006 & 0.023 & 0.024 \\
\hline
\end{tabular}

\subsubsection{Transformer}

All three-phase $150 / 6.3 \mathrm{kV}$ transformers are installed with a capacity of 30 / 35MVA. PT.Semen Indonesia has informed that each transformer will not be loaded with a capacity of more than $80 \%$ or $28 \mathrm{MVA}$. Meanwhile, the 6.3 / $0.4 \mathrm{kV}$ transformer is installed with different capacities for each substation. Each transformer is equipped with an OLTC (on load tap changer) of \pm $8 \times 1.25 \%$, which means there are a total of 16 steps and 17 steps.

\subsubsection{Load}

Electrical energy from the Indarung VI substation is distributed throughout the Cement Plant. Loads are divided into two categories, dynamic loads (motor) and static loads. PT. Semen Indonesia has provided a load list for each feeder at $6.3 \mathrm{kV}$. The data that will be used as input data for simulations for MV (medium voltage) loads are generally motors. As informed by PT. Semen Indonesia, for LV (low voltage) loads $90 \%$ of the load is dynamic load and $10 \%$ is static load. Each existing load will be recalculated using power $(\mathrm{kW})$ based on the FLSmidth standard. Load data from Indarung VI is shown in ANNEX 2.

Table 4.2 Load Characteristics of MV Motor.

\begin{tabular}{lllll}
\hline \multicolumn{1}{c}{ MV Motor } & $\begin{array}{c}\text { Rated } \\
\text { Power } \\
(\mathrm{kW})\end{array}$ & Efficiency (\%) & $\begin{array}{c}\text { Faktor } \\
\text { Daya }\end{array}$ & $\begin{array}{c}\text { Locked Rotor Current } \\
(\mathrm{pu})\end{array}$ \\
\hline Raw Mill Drive & 8700 & 97.3 & 0.87 & 7 \\
Raw Mill ID Fan & 7620 & 97.1 & 0.86 & 5.3 \\
Bag Filter Fan & 2001 & 96 & 0.95 & 8 \\
Pre Heater ID Fan & 2229 & 96 & 0.95 & 7 \\
Coal Mill Drive & 950 & 96 & 0.85 & 6 \\
Coal Mill ID Fan & 1700 & 96 & 0.85 & 6 \\
Cement Mill Drive & 5600 & 96.5 & 0.85 & 6.5 \\
Cement Mill ID Fan & 2930 & 96 & 0.95 & 7 \\
Limestone Crusher & 1400 & 96 & 0.85 & 5.5 \\
\hline
\end{tabular}

4.3. Power Flow Study Results

Power flow calculations are required in power system analysis studies and are widely used in systems planning, design and operation. Power flow analysis for several conditions of the operating scheme is determined to see the voltage on each busbar, the loading of each element 
such as CB (circuit breaker), DS (disconnecting switch), cables, busbars \& transformers on the network and to check the adequacy of the transformer taps to regulate voltage. The calculation method used is NewtonRaphson with an error of 0.001MVA.

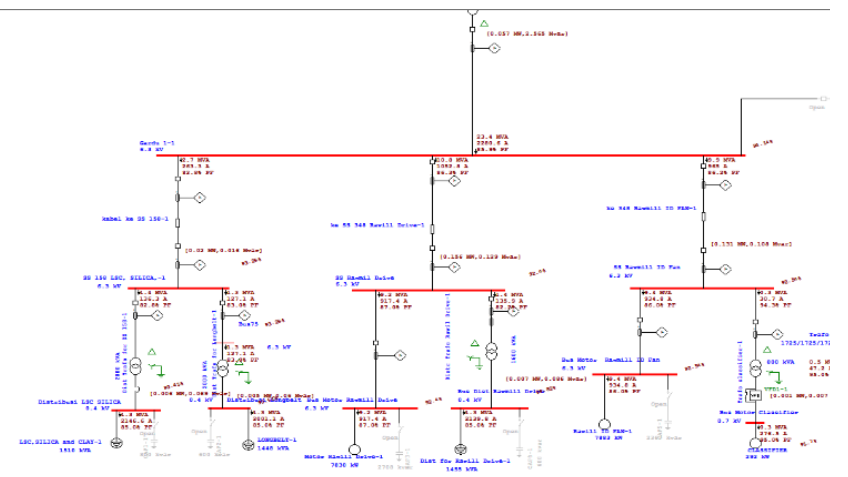

Figure 4.1 Power Flow Result at Trafo 1

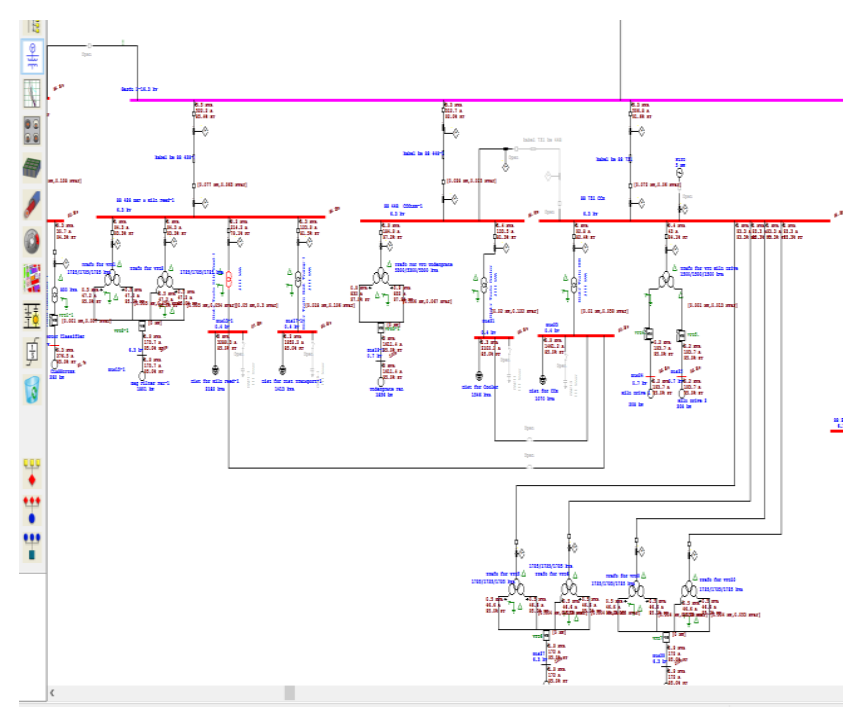

Figure 4.2 Power Flow Result at Trafo 2

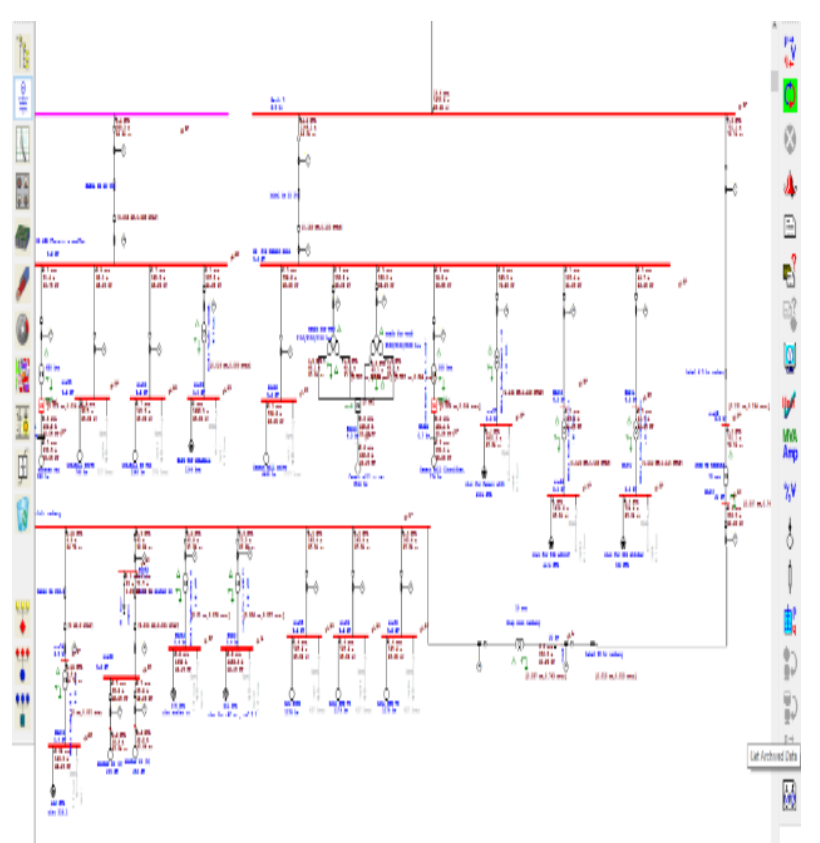

Figure 4.3 Power Flow Result at Trafo 3

4.3.1 Power Factor

Power flow simulation results for power factor values on the main buses are shown in Table 4.4.

Table 4. 4 Power Factors for Each Substation of Indarung VI Cement Plant before the Capacitor Bank Installation.

\begin{tabular}{|c|c|c|c|}
\hline Trafo & Bus ID & $\mathrm{kVar}$ & $\mathrm{PF}$ \\
\hline \multirow{3}{*}{ Trafo 1} & SS 158.LSC SILICA & 1515 & 82.8 \\
\hline & SS.348 rawwmill Drive & 5468 & 86.3 \\
\hline & SS.348 rawwmill ID Fan & 5028 & 86.2 \\
\hline \multirow{4}{*}{ Trafo 2} & SS 428. BHF\& KILN & 2850 & 85.4 \\
\hline & SS 448. COOLER & 1283 & 92 \\
\hline & SS 731. CCR & 2133 & 91.6 \\
\hline & SS 468 COALMILL \& RAWCOAL & 2164 & 84.8 \\
\hline \multirow{3}{*}{ Trafo 3} & SS 548 CEMENTMILL & 6059 & 86 \\
\hline & & & \\
\hline & SS 268 PIT LIMIT TAMBANG & 4909 & 76.1 \\
\hline
\end{tabular}

4.3.2 Power Factor Improvement

Capacitor bank is a collection of capacitors used to provide compensation for reactive power $(\mathrm{Qc})$.

Table 4. 5 KVAR Rating Value on Capacitor Bank

\begin{tabular}{|c|c|c|c|}
\hline Trafo & Bus ID & Nalki kapastitor & Total kVar \\
\hline \multirow{3}{*}{ Trafo 1} & SS 158.LSC SILICA & $\begin{array}{l}1 \text { buah } 800 \mathrm{kVar} \\
1 \mathrm{buah} 600 \mathrm{kVar}\end{array}$ & 1400 \\
\hline & SS.348 rawnmill Drive & $\begin{array}{l}1 \text { buah } 2708 \mathrm{kVar} \\
1 \text { buah } 600 \mathrm{kVar}\end{array}$ & 3308 \\
\hline & $\begin{array}{l}\text { SS. } 348 \text { rawnmill D Fan } \\
\text { SS 428. BHF \& KILN }\end{array}$ & $\begin{array}{l}1 \mathrm{buahh} 2367 \mathrm{kVar} \\
2 \text { buah } 800 \mathrm{kVar}\end{array}$ & $\begin{array}{l}2367 \\
1600\end{array}$ \\
\hline \multirow{3}{*}{ Trafo 2} & $\begin{array}{l}\text { SS 448. COOLER } \\
\text { SS 731. CCR }\end{array}$ & $\begin{array}{l}1 \text { buah } 800 \mathrm{kVar} \\
1 \text { buah } 800 \mathrm{kVar}\end{array}$ & $\begin{array}{l}800 \\
800\end{array}$ \\
\hline & & 1 buah $317 \mathrm{kVar}$ & \\
\hline & SS 468 COALMLL \& RAWCOAL & $\begin{array}{l}1 \text { buah } 578 \mathrm{kVar} \\
1 \text { buah } 600 \mathrm{kVar}\end{array}$ & 1495 \\
\hline \multirow{4}{*}{ Trafo 3} & & 1 buah $1717 \mathrm{kVar}$ & \\
\hline & SS 548 CEMENTNILL & 2 buah $800 \mathrm{kVar}$ & 3917 \\
\hline & & 1 buah $600 \mathrm{kVar}$ & \\
\hline & SS 268 PIT LINIT TAMBANG & $\begin{array}{l}3 \text { buah } 437 \mathrm{kVar} \\
3 \text { buah } 800 \mathrm{kVar}\end{array}$ & 3711 \\
\hline
\end{tabular}


Table 4. 6 Power Factor of the main buses of Indarung VI Cement Plant after Capacitor Bank Installation.

\begin{tabular}{|c|c|c|c|}
\hline Trafo & Bus ID & $\mathrm{kVar}$ & PF \\
\hline \multirow{3}{*}{ Trafo 1} & SS 158.LSC SILICA & 296 & 99.2 \\
\hline & SS.348 rawrumill Drive & 2434 & 96.8 \\
\hline & SS.348 rawumill ID Fan & 2833 & 94.9 \\
\hline \multirow{5}{*}{ Trafo 2} & SS 428. BHF\& KILN & 1404 & 96 \\
\hline & SS 448. COOLER & 595 & 98.2 \\
\hline & & & \\
\hline & SS 731. CCR & 1413 & 96.1 \\
\hline & SS 468 COALMILL \& RAWCOAL & 772 & 97.6 \\
\hline \multirow{3}{*}{ Trafo 3} & SS 548 CEMENTMILL & 2465 & 97.3 \\
\hline & & & \\
\hline & SS 268 PIT LIMIT TAMBANG & 982 & 98.7 \\
\hline
\end{tabular}

The power flow simulation results show that the Power Factor of all buses is above $85 \%$. This is because the capacitor bank that has been integrated with several loads has a power factor below $85 \%$. So it can be said that the power factor for the electrical system of the Indarung VI Cement Plant is already in a safe condition.

\subsection{Result of Short Circuit Study}

In this short circuit study, the amount of short circuit current on each bus is calculated and the amount of current contribution from each feeder connected to the bus that is short-circuited. This short circuit current calculation serves two purposes:

1. To determine the ability of the equipment to withstand sub-transient short circuit currents that may occur in the system. Equipment that is determined for its ability to withstand short circuit currents includes busbars on switchgear or MCC and circuit breakers for medium voltages.

2. To find out the maximum transient short circuit level on each bus and it is used for setting reference and coordination of safety relays.

Industrial electric power systems are designed so that loads are supplied safely and reliably. One of the main aspects taken into account in the design and operation of an electric power system is the handling when a short circuit fault occurs. A system designed to be able to isolate short circuit currents with minimal damage to equipment and systems. Furthermore, this calculation is needed to determine the coordination of protection relays.

The configuration of the electrical system when simulating a short circuit fault is

1. All $150 / 6.3 \mathrm{kV}$ transformers are turned on.
2. The bus coupler on each single busbar is off.

3. Supply only from PLN.

4. The capacitor bank of each substation is turned on.

To calculate short circuit current, ETAP 12.6 software is used. Minimum short circuit is 2 phase short circuit at 30 cycles. While the maximum short circuit is a 3 phase short circuit, on 1 / 2cycle.

Based on the simulation results above, it can be seen that the selection of a CB with an AC breaking capacity of 40 $\mathrm{kA}$ for a system voltage of $150 \mathrm{kV}$ and $6.3 \mathrm{kV}$ is correct. The largest 3-phase short circuit current of $30.62 \mathrm{kA}$ in a $6.3 \mathrm{kV}$ system occurs on the GI 1 bus. Whereas for the low voltage $0.4 \mathrm{kV}, \mathrm{CB}$ with a breaking capacity of AC $50 \mathrm{kA}$ with a maximum short circuit current of $43.52 \mathrm{kA}$ occurs at Bus dist (SS 158. LSC \& Silica).

4.5 Results of Setting and Coordination of Protection Relays

The Indarung VI Cement Plant electrical system requires a protection system to protect against various disturbances and abnormal conditions. The protection system works to isolate the affected parts as quickly as possible, and keep the healthy (undisturbed) parts operating normally. In the protection system, there is an arrangement of safety relays consisting of a main safety relay and a backup safety relay. Between the main safety relay with this backup safety relay must be coordinated in order to produce a protection system that is reliable, works fast, sensitive and selective. This coordination is carried out on the pickup current and time dial settings for several relays on the upstream and downstream sides. Determination of the protection setting for the transformer refers to the recommendation from ETAP, namely the pickup relay 51 setting of $110-140 \%$ of the nominal current. In this case the setting is done under the transformer damage curve and under the current capacity curve of the cable. While the pickup relay setting 50 is $200 \%$ of the inrush transformer (or practically 15 x FLA can be selected) and under the current capacity curve of the cable.

\subsubsection{Protection Relay Settings}

Pick-up flow setting

The pickup current is the minimum current value that causes the relay to work (Iset). In overcurrent relays, the amount of pickup current is determined by selecting the plug setting. As for determining the size of the plug setting using the following equation:

Plug setting $=$ Iset $* \mathrm{CT}$ ratio 
The pickup relay current setting must not touch the motor start curve and must be above the full load ampere (FLA) of the transformer and below the minimum fault current. Time dial setting

The time dial setting determines the relay operation time. To determine the time dial of each overcurrent relay with the inverse characteristic (51), the following equation can be used:

$$
t=\frac{T M S x \beta}{(P S M)^{\alpha}-1}
$$

Where:

$\mathrm{t}=$ operating time (second)

TMS = Time Multiplier Setting / Time dial

PSM $=$ Plug Setting Multiplier $=\mathrm{I} /$ Iset

If $=$ Short circuit current at the end of the line (Ampere)

Iset $=$ Current setting (Ampere), $\alpha, \beta=$ The following constants:

For static relays and digital relays based on microprocessor, the overt-travel time of the relays can be neglected, so that the total working time of the relay until the circuit breaker opens is $0.2-0.4$ seconds. On the basis of the standard calculation above, the relay working time until the $\mathrm{CB}$ opens is chosen 0.3 seconds. This time difference is to ensure that the downstream disturbance has been successfully extinguished, so that the possibility of simultaneous trips can be avoided.

\subsubsection{Protection Relay Coordination}

Security relay settings that go through the line from the Main Substation to the Sub Station must be coordinated. Example of calculating the setting and coordination of bag filter relays, 428 relays and $6.3 \mathrm{kV}$ incoming relays. The protection relay setting starts from the most downstream relay, namely the Relay Bag Filter, then the feeder relay to bus 428 or relay 428 and finally the upstream relay, namely the incoming $6.3 \mathrm{kV}$ relay.

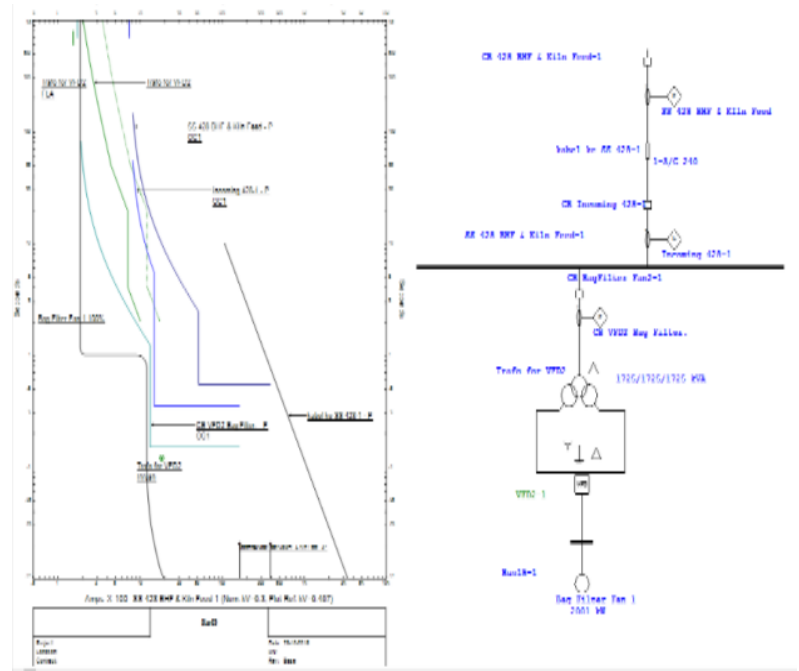

Figure 4. 4 Relay security line SS 428 bus filter bag and time flow curve.

\subsubsection{Results of Relay Protection Settings and} Coordination

Example :Safety Relay on Main Substation Transformer 1

Table 4. 7 Results of pickup flow and time dial settings

\begin{tabular}{|c|c|c|c|c|c|c|c|c|}
\hline \multirow[b]{2}{*}{ Relay Name } & \multirow[b]{2}{*}{ Voltage (kr) } & \multicolumn{2}{|c|}{ Ratio CT } & \multirow[b]{2}{*}{ Curve } & \multicolumn{2}{|c|}{ Pickup } & \multirow[b]{2}{*}{ Top } & \multirow{2}{*}{$\begin{array}{l}\text { Tim } \\
\text { Dia }\end{array}$} \\
\hline & & $\begin{array}{c}\text { Prima } \\
\text { ry }\end{array}$ & $\begin{array}{c}\text { Second } \\
\text { ary }\end{array}$ & & Primary & Secozdary & & \\
\hline $\begin{array}{l}\text { SS } 158 \text { LSC \& } \\
\text { Silica Storage \& } \\
\text { Transport }\end{array}$ & 6.3 & 2000 & 5 & $\mathrm{vI}$ & 403.26 & 1.008 & 0.5 & 2.775 \\
\hline Incoming 158 & 6.3 & 600 & 3 & $\mathrm{vr}$ & 403.26 & 0.672 & 0.3 & 0.904 \\
\hline $\begin{array}{l}\text { Rolay LSC \& } \\
\text { SHLICA }\end{array}$ & 6.3 & 300 & 2 & $\mathrm{v1}$ & 201.63 & 0.672 & 0.1 & 0.610 \\
\hline Rolay Lomgbolt & 6.3 & 300 & 3 & $\mathrm{vr}$ & 201.63 & 0.672 & 0.1 & 0.610 \\
\hline $\begin{array}{l}\text { SS } 348 . \\
\text { RAWWIILL ID } \\
\text { FAN }\end{array}$ & 6.3 & 2000 & 5 & $\mathrm{v} 1$ & 994.081 & 0.497 & 0.6 & 1.325 \\
\hline $\begin{array}{l}\text { Incoming } 348 \text { ID } \\
\text { FAN }\end{array}$ & 6.3 & 2000 & 3 & $\mathrm{vr}$ & 994.081 & 0.497 & 0.4 & 0.691 \\
\hline $\begin{array}{l}\text { Rolay Rankill ID } \\
\text { FAN }\end{array}$ & 6.3 & 1200 & 5 & $\mathrm{vr}$ & 913.44 & 0.761 & 0.2 & 0.377 \\
\hline Rolay Clasifor & 6.3 & 200 & 3 & $\mathrm{vr}$ & 80.641 & 0.403 & 0.1 & 2.213 \\
\hline $\begin{array}{l}\text { SS 348.RAWMMILL } \\
\text { DRIVE }\end{array}$ & 6.3 & 2000 & 5 & $\mathrm{vI}$ & 1262.82 & 0.631 & 0.6 & 1.229 \\
\hline $\begin{array}{l}\text { Relay Incoming } \\
\text { Rawmill Drive }\end{array}$ & 6.3 & 2000 & 5 & $\mathrm{vr}$ & 1068.54 & 0.534 & 0.4 & 0.663 \\
\hline $\begin{array}{l}\text { Rolay Distribusi } \\
\text { Ravumill Drive }\end{array}$ & 6.3 & 300 & 3 & $\mathrm{v} 1$ & 161.26 & 0.538 & 0.1 & 1.140 \\
\hline $\begin{array}{l}\text { Rolay Rawaill } \\
\text { drive }\end{array}$ & 6.3 & 1200 & 5 & $\mathrm{vr}$ & 907.28 & 0.756 & 0.2 & 0.393 \\
\hline $\begin{array}{l}\text { Rolay } 6,3 \text { kV Bus } \\
\text { Soction } 1\end{array}$ & 6.3 & 3500 & 3 & $\mathrm{vr}$ & 2335.5 & 0.724 & 0.8 & 0.656 \\
\hline $\begin{array}{l}\text { Relay ircoming } 6,3 \\
\text { kT }\end{array}$ & 6.3 & 3500 & 3 & $\mathrm{v1}$ & 3023.9 & 0.864 & 1 & 0.676 \\
\hline $\begin{array}{l}\text { Relay ircomixg } \\
150 \mathrm{kv}\end{array}$ & 150 & 150 & 1 & $\mathrm{vr}$ & 127.05 & 0.847 & 1.2 & 0.802 \\
\hline
\end{tabular}

sudut penyalaan terhadap kecepatan motor jarang dibahas. Sedangkan pengaturan frekuensi pada cycloconverter berbasis TRIAC dilakukan dengan cara pengaturan sudut penyalaannya sehingga sangat penting untuk menganalisis hubungan antara sudut penyalaan terhadap besaran-besaran pada motor induksi satu fasa. Pada penelitian ini akan dilakukan analisis pengaruh sudut penyalaan TRIAC terhadap besaran-besaran pada motor induksi satu fasa yaitu tegangan, daya keluaran motor dan kecepatan motor.

\section{CONCLUSION AND SUGGESTION FOR FUTURE DESIGN}

Design of pneumatics conveying system can increase clinker production to reach design capacity 7800 ton/hour

Based on the simulation and analysis results for the electrical protection system of PT Semen Padang's Indarung VI Cement Plant using ETAP 12.6, the following conclusions are obtained:

a. The simulation results of the power flow study show that the capacitor bank can improve the power factor of the Indarung VI Cement Plant electrical system from a value below $85 \%$ to above the standard set by PLN, which is $85 \%$.

b. The installation of bank capacitors also affects the electrical system voltage value of the Indarung VI Cement Plant with an average increase of $3 \%$.

c. Some buses in the Indarung VI Cement Plant electrical system that are still experiencing under-voltage 
conditions can be repaired using a tap changer so that the system voltage is in accordance with the permitted voltage standard range, namely.

d. Installation of capacitor banks and changer settings also affects the amount of power to be sent by PLN with the following conditions:

Prior to: 64.1 MVA

After: 55.9 MVA

So that the power reduction value of $8.2 \mathrm{MVA}$ is obtained.

e. The largest 3-phase short circuit current is 30.62 $\mathrm{kA}$ in the $6.3 \mathrm{kV}$ system occurring on the GI 1 bus. Whereas for the low voltage $0.4 \mathrm{kV} \mathrm{CB}$ is used with an $\mathrm{AC}$ breaking capacity of $50 \mathrm{kA}$ with a maximum short circuit current of $43.52 \mathrm{kA}$ occurs at Bus dist ( SS 158. LSC \& Silica). Based on the simulation results above, it can be seen that the selection of a $\mathrm{CB}$ with an $\mathrm{AC}$ breaking capacity of $40 \mathrm{kA}$ for a system voltage of 150 $\mathrm{kV}$ and $6.3 \mathrm{kV}$ and an $\mathrm{AC}$ breaking of $50 \mathrm{kA}$ for a system voltage of $0.4 \mathrm{kV}$ is correct.

f. The design of protection relay coordination for PT Semen Padang's Indarung VI Plant was carried out by a combination of time inverse and instaneous characteristics.

g. The simulation results show that there is no misscoordination between the main relay and the back-up relay, this shows that the work coordination between relays can run well.

\subsection{Suggestions}

The design of an industrial electrical system must be carried out with more complex studies and theoretical calculations in order to obtain accurate values and the creation of an electrical system that is safe, reliable and economical.

\section{REFERENCES}

[1] A. El Faruqi, "PT Semen Padang Bangun Pabrik Keenam," 2014. [Online]. Available: https://m.tempo.co/read/news/2014/05/27/0905805 44/pt-semen-padang-bangun-pabrik-keenam. [Accessed: 30-Sep-2016].

[2] Power Systems Engineering Committee of the IEEE Industri Applications Society, IEEE Std 399-1997 Recommended Practice for Industrial and Commercial Power Systems Analysis, vol. 1995, no. Lcc. 1995.

[3] H. Saadat, Power System Analysis. New York: The McGraw-Hill Companies, 2002.

[4] D. Sulistiyono, "Perbandingan Metode Gauss Seidel, Metode Newton Raphson dan Metode Fast Decoupled dalam Solusi Aliran Daya," Universitas Diponegoro, 2011.

[5] FLSmidth, "Power distribution system: design basis," 2013.

[6] Power Systems Engineering Committee, IEEE Std 141-1993 Recommended Practice for Electric Power Distribution for Industrial Plants, vol. 1993. 1990.

[7] J. V. H. Sanderson, IEEE Std 242-2001 Recommended Practice for Protection and Coordination of Industrial and Commercial Power Systems, vol. 3, no. 2. 1989.

[8] International Electrotechnical Commission, IEC 60909-0, First Ed. Geneva, 2001.

[9] J. Melorose, R. Perroy, and S. Careas, Protection of Electrical Networks, First Ed., vol. 1. London: ISTE Ltd, 2015. 